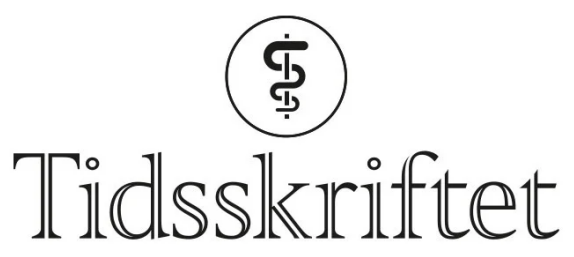

DEN NORSKE LEGEFORENING

\title{
Gestagen eller progestin?
}

KOMMENTAR

METTE HAASE MOEN

mette.moen@ntnu.no

Mette Haase Moen er professor emerita i gynekologi ved NTNU Trondheim.

Forfatteren har ikke oppgitt noen interessekonflikter.

I Språkspalten forsøker Guttorm Raknes (1) å rydde opp i terminologien omkring kunstig fremstilt progesteron, blant annet ved å gjennomgå terminologien brukt i engelsk- og tysktalende land. Han konkluderer med at den rette betegnelsen bør være "progestin» for å unngå forvekslinger. Hva mener brukerne? I norske lærebøker i gynekologi og i Norsk legemiddelhåndbok brukes konsekvent ordet gestagen. I Felleskatalogen får man 77 svar ved å søke på gestagen, 14 ved å søke på progestin. I et nettsted for gynekologer med interesse for hormoner stilte jeg 10. juni spørsmålet: Hvilket ord er mest naturlig for dere å bruke, progestin eller gestagen? 172 svarte gestagen og én svarte progestin. En henvendelse til kolleger i nøkkelposisjon i Sverige og Danmark om samme spørsmål ble besvart med at de bruker ordet "gestagen» om det kunstige progesteron. Det er ikke et problem å lese angelsaksisk litteratur hvor det er ulike tradisjoner for ordvalg. La oss i Norge som i Skandinavia beholde "progesteron» for det som produseres i kroppen og "gestagen» for det som produseres av legemiddelindustrien. Ved behov for samlebetegnelse, vil det mest logiske bli «progestagener».

Under beskrivelse av progesterons effekt omtales at en viktig biologisk funksjon er østrus (brunst). Eksemplet var dårlig valgt, for det er østrogen som er relatert til brunst (østrus). Den fertile periode i menstruasjonssyklus faller sammen med det høyeste nivå av østrogen og lavt nivå av progesteron. Etter ovulasjon faller fertiliteten mot null, og nå produseres progesteron fra corpus luteum for å utvikle livmorslimhinnen og videre for å beskytte graviditeten til placenta overtar hormonproduksjonen.

Forfatteren beskriver at progesteron er lite egnet som legemiddel på grunn av ugunstig farmakokinetisk profil. Progesteron brukes rutinemessig i fertilitetsbehandling. Det er en stigende interesse for å bruke naturlig progesteron som tillegg til østradiol i

klimakteriebehandling. Data tyder på at denne kombinasjonen er gunstigere enn østradiol og gestagener med hensyn til risiko for brystkreft (2). Ifølge reseptregisteret.no brukte i 2020 mer enn 12 tusen kvinner progesteron.

Gestagen er viktigste komponent i hormonell prevensjon, dels som ren gestagenbehandling, og dels sammen med østrogen i den kombinerte p-pillen. Forfatteren har allerede beklaget og rettet klassifisering av gestagener i forhold til 'generasjonsbegrepet'. Det skal jeg ikke utdype, men det viser at det selv på ekspertplan kan oppstå forvirring. 
Kanskje best å forlate "generajsonsgruppering» og konsentrere seg om de enkelte gestagener og deres betydning for den kombinerte p-pilles tromboserisiko? Kombinerte ppiller med noretisteron, levonorgestrel eller norgestimat (som spaltes til levonorgestrel) har lavere tromboserisiko enn de øvrige kombinerte p-piller på det norske markedet. Det er sikrere å huske preparatnavn enn hvilken generasjon gestagenet tilhører.

Innlegget i språkspalten viser ikke bare vanskelighet med terminologien, men at endokrinologi kan være vanskelig. For gynekologer er opprettet en Facebook-gruppe for diskusjon av hormonelle spørsmål «Hormoner og endometriose» hvor andre kolleger er velkomne til å delta.

\section{LITTERATUR}

1. Raknes G. Progestageners terminologi. Tidsskr Nor Legeforen 2021; 141. doi:10.4045/tidsskr.21.0o66. [CrossRef]

2. Stevenson JC, Rozenberg S, Maffei S et al. Progestogens as a component of menopausal hormone therapy: the right molecule makes the difference. Drugs Context 2020; 9: 2020-10-1. [PubMed] [CrossRef]

Publisert: 16. august 2021. Tidsskr Nor Legeforen. DOI: 10.4045/tidsskr.21.0528

(C) Tidsskrift for Den norske legeforening 2023. Lastet ned fra tidsskriftet.no 26. april 2023. 